\title{
SALINITY MEASUREMENTS COLLECTED BY FISHERMEN REVEAL A "RIVER IN THE SEA" FLOWING ALONG THE EASTERN COAST OF INDIA
}

by A. V. S. Chaitanya, M. Lengaigne, J. Vialard, V. V. Gopalakrishna, F. Durand, C. Kranthikumar, S. Amritash, V. Suneel, F. Papa, and M. Ravichandran

Measurements of salinity by fishermen in knee-deep water reveal a seasonal "river in the sea" flowing along the eastern coast of India

T he Indian Ocean is the only tropical ocean that is entirely bounded by a landmass to the north. In boreal summer, this unique geographical setting allows for a large differential heating between the Asian subcontinent and the ocean to the south that drives the most dramatic monsoonal wind system in the world. The southwest monsoon roughly lasts from June to September. During these four months, water vapor collected at the ocean surface by the powerful southwesterly winds is flushed over India and the Bay of Bengal (BoB; see Fig. 1a).

Monsoonal rains feed several large river basins over the Indian subcontinent (Fig. 1a). A large fraction of the runoff to the ocean occurs during or shortly after the southwest monsoon and contributes to the freshwater flux into the $\mathrm{BoB}$ in equal proportion with rainfall over the ocean (Fig. 1b). The largest rivers that flow into the $\mathrm{BoB}$ are the Ganges-Brahmaputra and the Irrawaddy, whose long-term average discharges at the river mouths during July-September amount to approximately $8.7 \times 10^{4} \mathrm{~m}^{3} \mathrm{~s}^{-1}$ and $3.4 \times 10^{4} \mathrm{~m}^{3} \mathrm{~s}^{-1}$, respectively (Papa et al. 2012; (a) Rainfall and runoffs during monsoon

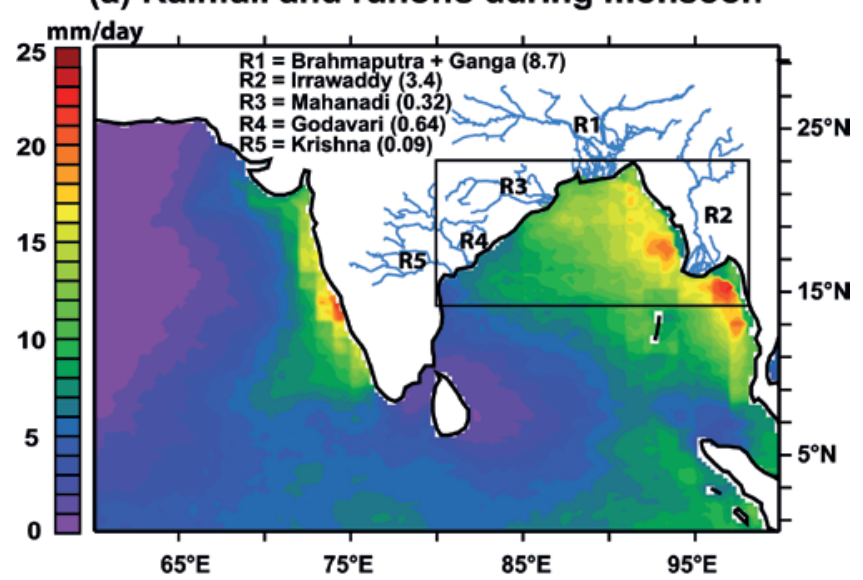

(b) Seasonal cycle of rainfall and runoffs

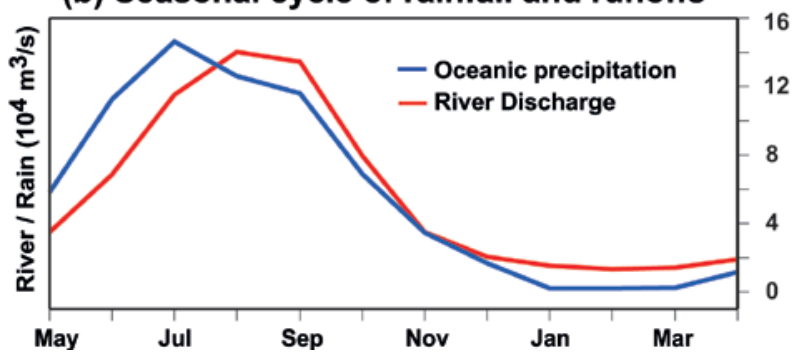

FIG. I. (a) Average climatological rainfall from Jul to Sep (mm day ${ }^{-1}$ ) from Tropical Rainfall Measuring Mission (TRMM) 3B42 data. The major rivers in the northern BoB are drawn on the map and their average river discharge during Jul-Sep $\left(10^{4} \mathrm{~m}^{3} \mathrm{~s}^{-1}\right)$ is indicated. (b) Average freshwater flux into the $B o B\left(10^{4} \mathrm{~m}^{3} \mathrm{~s}^{-1}\right)$ north of $14^{\circ} \mathrm{N}$ from rainfall over the ocean (blue curve) and the major rivers (red curve) indicated in (a). Refer to the online supplement for a complete description of the datasets used in this article. 


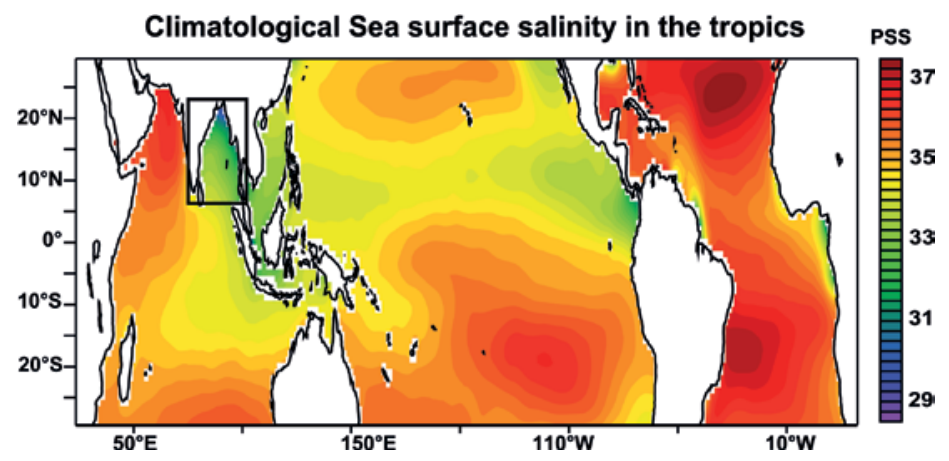

FIG. 2. Annual average SSS in the tropics from the Chatterjee et al. (20I2) climatology.

Dai and Trenberth 2002). Three other smaller rivers on the eastern Indian coast (Mahanadi, Godavarim, and Krishna) together contribute approximately $10^{4} \mathrm{~m}^{3} \mathrm{~s}^{-1}$. As a result, these five river systems bring on average a total of approximately $1100 \mathrm{~km}^{3}$ of continental freshwater into the BoB between July and September.

This very intense freshwater flux into a relatively small and semienclosed basin results in an intense dilution of the salt contained in seawater. While most of the tropics display annual average sea surface salinities (SSS) in excess of $34 \mathrm{~g} \mathrm{~kg}^{-1}$ (this salinity scale is referred to as the practical salinity scale; Millero et al. 2008), the BoB stands out as the largest

AFFiliations: Chaitanya, Gopalakrishna, KRANTHIKUMar, AND SUNEEL-NIO, CSIR, Goa, India; LeNGAIGNe-Sorbonne Universités-CNRS-IRD-MNHN, LOCEAN Laboratory, IPSL, Paris, France, and Indo-French Cell for Water Sciences, and NIO, CSIR, Goa, India; VIALARD-Sorbonne Universités-CNRSIRD-MNHN, LOCEAN Laboratory, IPSL, Paris, France, and Indo-French Cell for Water Sciences, Goa, India; DURANDLEGOS, Toulouse, France; AMRITASH-NIO, CSIR, Kochi, India; PAPA_LEGOS, Toulouse, France, and Indo-French Cell for Water Sciences, Bangalore, India; RAVICHANDRAN-INCOIS, Ministry of Earth Sciences, Hyderabad, Andhra Pradesh, India

National Institute of Oceanography contribution number 5546

CORRESPONDING AUTHOR: V. V. Gopalakrishna, Physical Oceanography Division, National Institute of Oceanography, Council of Scientific and Industrial Research, Dona Paula, Goa 403 004, India

E-mail: gopal@nio.org

The abstract for this article can be found in this issue, following the table of contents.

DOI:10.1175/BAMS-D-12-00243.1

A supplement to this article is available online (10.1175/BAMS-D-12-00243.2) In final form 25 March 2014

(C)2014 American Meteorological Society area of SSS below 33 units anywhere in the tropics (Fig. 2). The freshest surface water is found in the northern $\mathrm{BoB}$, where most of the river runoff and rainfall occur (Fig. 1a). The diluting effect of rainfall and river runoff is concentrated within the upper $40 \mathrm{~m}$ in the BoB, resulting in a stark contrast between surface freshwater and subsurface saltier water below and hence a sharp near-surface haline stratification (Figs. 3a,b).

This very strong salinity stratification in the $\mathrm{BoB}$ is thought to have important implications for the regional climate. The enhancement of near-surface ocean stability by salinity stratification could be part of a positive feedback loop that maintains high sea surface temperature (SST) and rainfall over the BoB (Shenoi et al. 2002). The salinity stratification indeed contributes to maintain a shallow mixed layer in the BoB that is efficiently warmed by surface heat flux and hence the SST remains above $28.5^{\circ} \mathrm{C}$ (de Boyer Montégut et al. 2007), a necessary condition to maintain deep atmospheric convection and rainfall (e.g., Gadgil et al. 1984). Similarly, this salinity stratification may also influence the intensity of the tropical cyclones that form over the BoB; the intense salinity stratification in the BoB after the monsoon inhibits vertical mixing and SST cooling below cyclones (Sengupta et al. 2008; Neetu et al. 2012), promoting an intense evaporation at the ocean surface and hence eventually the intensification of cyclones (e.g., Schade and Emanuel 1999). Last but not least, salinity could act as a marker of changes in the water cycle associated with anthropogenic forcing (e.g., Durack and Wijffels 2010; Terray et al. 2012). Monitoring salinity in the BoB, a small semienclosed basin that collects large quantities of freshwater from monsoonal rain and river runoffs, may hence be an efficient way to monitor long-term changes in monsoonal rain intensity. These climatic implications call for an improved description and understanding of the BoB salinity structure.

Most of the early descriptions of salinity in the BoB relied on sparse hydrographic salinity data issued from oceanographic cruises and shipping lanes (see "Salinity observations in the Bay of Bengal" for more details). Compiling these data, Rao and Sivakumar (2003) reported a marked seasonal cycle of salinity, with the largest signals occurring along the rim of the bay. While surface salinity remains relatively high before the monsoon onset (Fig. 3a), existing salinity climatologies compiled from available sparse hydrographic data (Chatterjee et al. 2012; Antonov et al. 


\section{SALINITY OBSERVATIONS IN THE BAY OF BENGAL}

$0_{\mathrm{tan}}^{\mathrm{cos}}$ cean salinity measurements are less frequently available than temperature measurements. This is partly due to scientific reasons: temperature variations often dominate density variations in the ocean, especially in the tropics. But the main reason is of a technical nature: measuring salinity is nowadays accomplished by measuring the conductivity of seawater which depends upon both its temperature and salinity. Conductivity sensors are more expensive, more fragile, and more prone to systematic drift than temperature sensors.

Historically, most of the salinity measurements were collected from scientific cruises (green dots in Fig. SBIa). Salinity was originally measured from the analysis of water samples collected at standard depths. There are about 4,600 such salinity profiles for the entire BoB in the World Ocean Database 2009 (WOD09; Boyer et al. 2009). More recently, conductivity-temperature-depth (CTD) casts operated from research vessels allow collecting higher-resolution profiles of salinity (about I,000 profiles in the BoB in WOD09). The number of available salinity measurements in the $B \circ B$ has increased astronomically with the advent of the Argo (http://wo.jcommops.org/cgi-bin/WebObjects/Argo) and the Research Moored Array for African-Asian-Australian Monsoon Analysis and Prediction (RAMA; McPhaden et al. 2009) international research programs. RAMA is an effort to develop a moored buoy array in the tropical Indian Ocean similar to those that already exist in the Pacific and Atlantic Oceans. There are now three such moorings in the BoB at $8^{\circ}, 12^{\circ}$, and $15^{\circ} \mathrm{N}$ along $90^{\circ} \mathrm{E}$ (red squares in Fig. SBla) that transmit daily-average salinity profiles in near-real time (4,380 profiles available in total in WOD09). The Argo program is a coordinated effort to deploy autonomous profilers that remain parked near $1000-\mathrm{m}$ depth and that perform a 0-2000-m CTD cast every 10 days while ascending vertically to the surface, before transmitting their data via satellite communication and returning to their parking depth. The number of Argo profiles really began to rise after 2002 in the Indian Ocean, and there are now about 13,000 such available profiles for the BoB in the WOD09 dataset (pink dots in Fig. SBIa).

In situ measurements of salinity have recently been complemented by the development of remote sensing capabilities of ocean surface salinity. The SMOS (Kerr et al. 20I0) and Aquarius (Levine et al. 2007) satellites measure microwave radiations emitted from the Earth's surface, at wavelengths where surface emissivity is most sensitive to ocean surface salinity. If corrected accurately from the other effects that modulate this emissivity (sea surface temperature, atmospheric composition, sea state, etc.), this allows for estimating the surface ocean salinity. SMOS and Aquarius surface salinity products are still very new and have not yet been thoroughly evaluated in many regions of the world. Preliminary studies, however, point out that, while remotely sensed salinity is rather accurate in the equatorial Indian Ocean (Durand et al. 2013; Shinoda et al. 2013), it is of poorer quality in the BoB (Ratheesh et al. 2013), partly due to strong radio interference with radars close to the coast (Reul et al. 2012).
Remote sensing of salinity near the eastern coast of India is hence currently challenging. In addition, there are also many fewer available in situ data within $50 \mathrm{~km}$ of the coast than in the open ocean (Fig. SBIb). This is partly because Argo profilers, with a parking depth of $1,000 \mathrm{~m}$, cannot access the Indian continent shelf, which is typically shallower than $200 \mathrm{~m}$. Most of the data very close to the Indian coast hence consist of historical cruise data, like the December 1991 cruise along the eastern coast of India described in Shetye et al. (1996).

(a) Map of available in-situ observations from WOD09

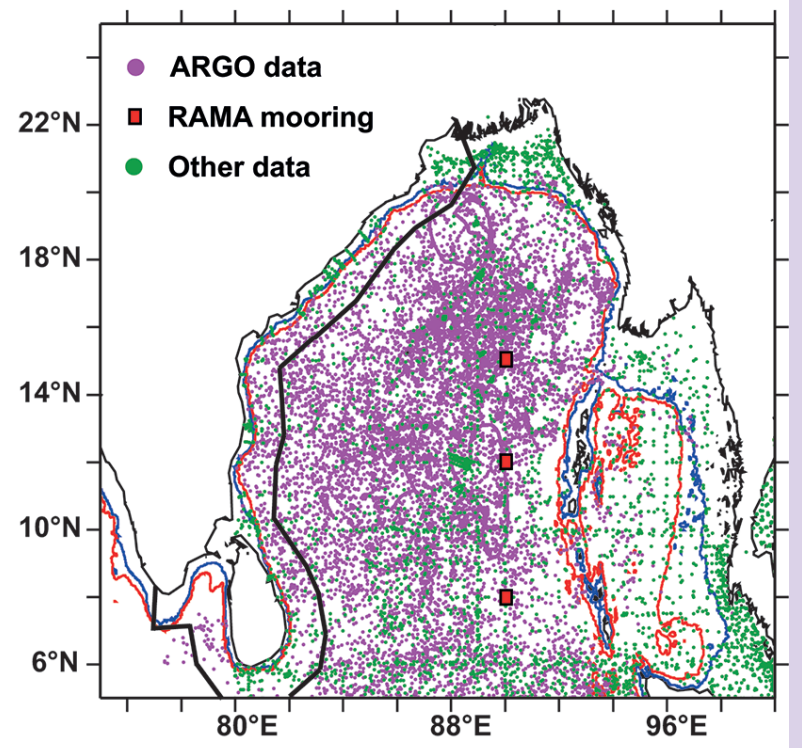

(b) Number of observations as a distance to the coast

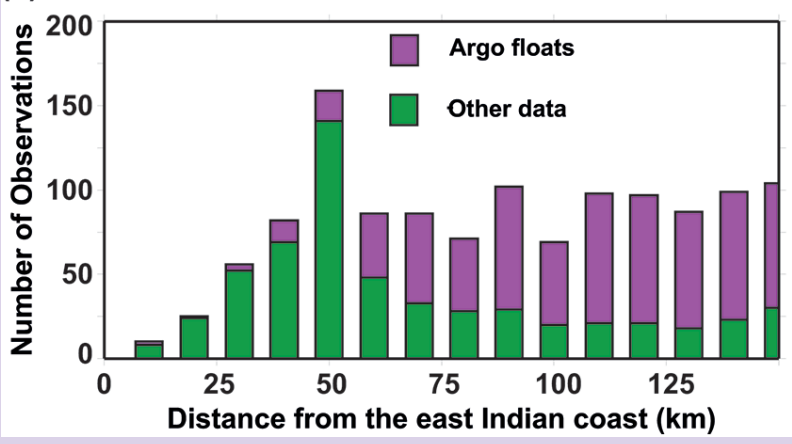

FIG. SBI. (a) Map of available SSS observations in the WOD09 (Boyer et al. 2009) from Argo profilers (pink), RAMA moorings (red squares), and other datasets (green). The blue and red contours indicate ocean depths of 200 and $1000 \mathrm{~m}$, respectively. The black contour delineates the area for which statistics are computed from (b) the number of observations in the western BoB as a function of the distance to the coast (in 10-km bins). Argo data are shown in pink and other datasets are shown in green. 

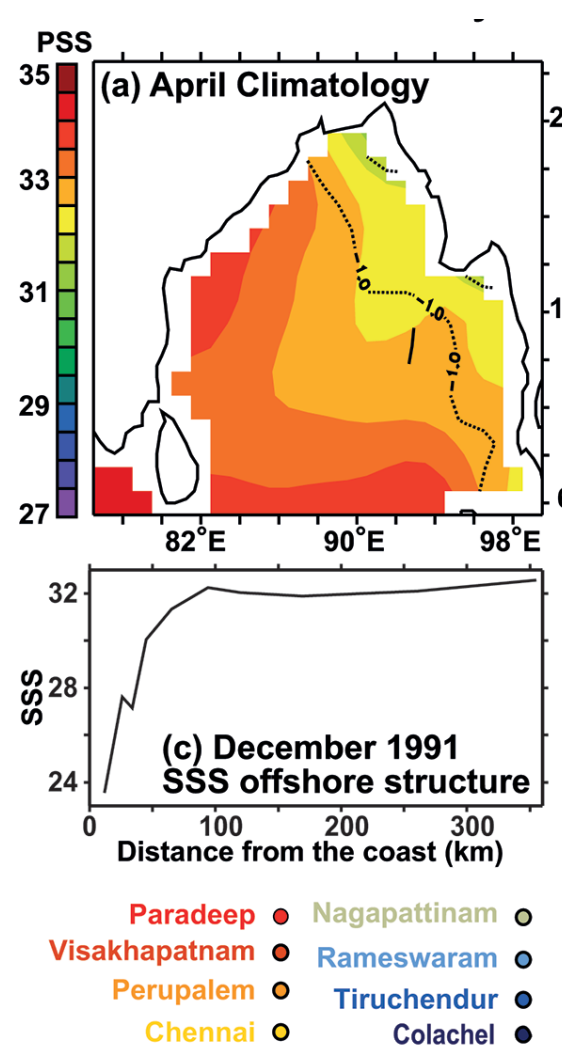

FIG. 3. Climatological map of SSS from Chatterjee et al. (20I2) in (a) Apr and (b) Nov (the contours show the surface salinity minus the salinity at $50-\mathrm{m}$ depth). (c) SSS measured during the Dec 1991 cruise described in Shetye et al. (1996) along the transect indicated by the black dashed line offshore of Paradeep displayed in (d). (d) Map of SSS in Dec 1991 derived from in-situ measurements performed during an oceanic cruise (adapted from Shetye et al. 1996). The colored circles in (d) indicate the location of the eight salinity coastal measurements stations used in that study (i.e., Paradeep, Visakhapatnam, Perupalem, Chennai, Nagapattinam, Rameshwaram, Tiruchandur, and Colachal) when following the coast from the northern BoB toward the western coast of India. The Chennai-Port Blair transect is indicated by the black continuous line, while the transect in (c) is indicated by the black dashed line.
(Fig. 3c). Shetye et al. (1996) further suggested that the southward expansion of the freshwater tongue following the monsoon was the result of transport by the narrow seasonal current that flows southward along the eastern coast of India from October to December (see "The East Indian Coastal Current”).

SSS measurements close to the eastern coast of India are currently not widely available because satellite remote sensing observations of salinity do not perform well in the region and autonomous profilers cannot access the shallow Indian continental shelf (see "Salinity observations in the Bay of Bengal" for more details). Most of the observations located very close to the Indian coast were collected during historical cruises, like the cruises of Shetye et al. (1996) and Hareesh Kumar et al. (2013). Until recently, there was no dataset that allowed resolving the seasonal march of this
2010) depict a strong freshening after the monsoon in the northeastern part of the bay (Fig. 3b) that has been clearly attributed to the monsoonal freshwater forcing from rainfall and rivers (e.g., Shetye et al. 1996; Rao and Sivakumar 2003; Sengupta et al. 2006). These low-salinity waters further expand southward as a fresh tongue along the coast of India down to Sri Lanka in the following months (Fig. 3b). These salinity climatologies depict this freshening along the eastern coast as a rather broad offshore extent ( $\sim 00 \mathrm{~km}$ wide) with SSS remaining above 31 units. Two Indian oceanographic cruises in December 1991 (Shetye et al. 1996) and December 1997 (Hareesh Kumar et al. 2013), however, offer a more contrasted picture, with a narrow-approximately $50-100-\mathrm{km}$ wide-freshwater strip that hugs the coast of India (Fig. 3d) with SSS as low as 23.5 units off Paradeep freshwater tongue along the eastern coast of India. Over the past eight years, the Council of Scientific and Industrial Research's National Institute of Oceanography (CSIR-NIO, Goa, India) has developed an innovative observing system to monitor the salinity evolution along the east Indian coast in which fishermen collected seawater samples at eight stations along the Indian coastline. The remainder of this paper is organized as follows. We first describe this program funded by India's Ministry of Earth Sciences and present evidence that this simple, cost-effective sampling strategy is representative of offshore salinity evolution, revealing a "river in the sea" (a narrow strip of very freshwater that hugs the coast) flowing southward along the eastern coast of India shortly after the southwest monsoon. We then describe the seasonal 
march of this river in the sea and discuss the mechanisms driving its evolution. We finally summarize the main findings of this paper and discuss the relevance and possible future developments of this observing system based on local fishermen.

\section{INDIAN FISHERMEN MEASURING} ONSHORE SALINITY. Modern technologies offer innovative ways of monitoring salinity along the Indian coast. A series of moorings, or repeated sections with expandable conductivity-temperature-depth probes or gliders (autonomous vehicles that can perform highresolution temperature and salinity sections) could, for example, provide a monitoring of salinity along the coast, but at a high cost. Such a coastal observing system does not exist at present. Since May 2005, CSIRNIO conducts a very cost-effective program operated by fishermen to measure salinity at stations scattered along the Indian coastline. In this section, we describe this simple measurement strategy and show that it accurately captures the variations of the narrow strip of very freshwater that hugs the eastern coast of India.

Local fishermen were recruited at eight stations along the eastern coast and near the southern tip of India. Those stations (see Fig. 3d for their locations and "Velipalaiyam, a fishermen's village,

\section{THE EAST INDIAN COASTAL CURRENT}

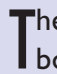
he The East Indian Coastal Current (EICC) is the western boundary current of the $\mathrm{BoB}$. The EICC reverses twice a year under the influence of alternating monsoons (e.g., Shankar et al. 1996; McCreary et al. 1996; Durand et al. 2009): it flows northward from February to September and southward from October to January (see Fig. SB2). The EICC does not always flow in the direction expected from the local winds, and sometimes it opposes local winds because of a strong influence of remote forcing. This remote forcing manifests under the form of coastal Kelvin waves (coastally trapped waves that travel counterclockwise around the BoB at a speed of approximately 2.5-3 $\mathrm{m} \mathrm{s}^{-1}$ ). These Kelvin waves can be forced by alongshore wind variations along the northern and eastern boundaries of the bay or even originate from the equatorial region. Wind fluctuations in the interior of the BoB also force westward-traveling Rossby waves, which travel to the eastern coast of India and also contribute to the EICC variations. During the period of southward flow from October to January, the EICC is mostly driven by local winds and wind fluctuations in the BoB's interior (McCreary et al. 1996).

Sitting on a western ocean boundary, another noticeable feature of the EICC is its very narrow structure (Figs. SB2b,c; Shetye et al. 1996) as compared to eastern boundary currents (the western coasts of India and Burma, e.g., display much broader coastal currents). Durand et al. (2009) indeed showed that the typical offshore scale of the EICC is commensurate with the "Rossby radius
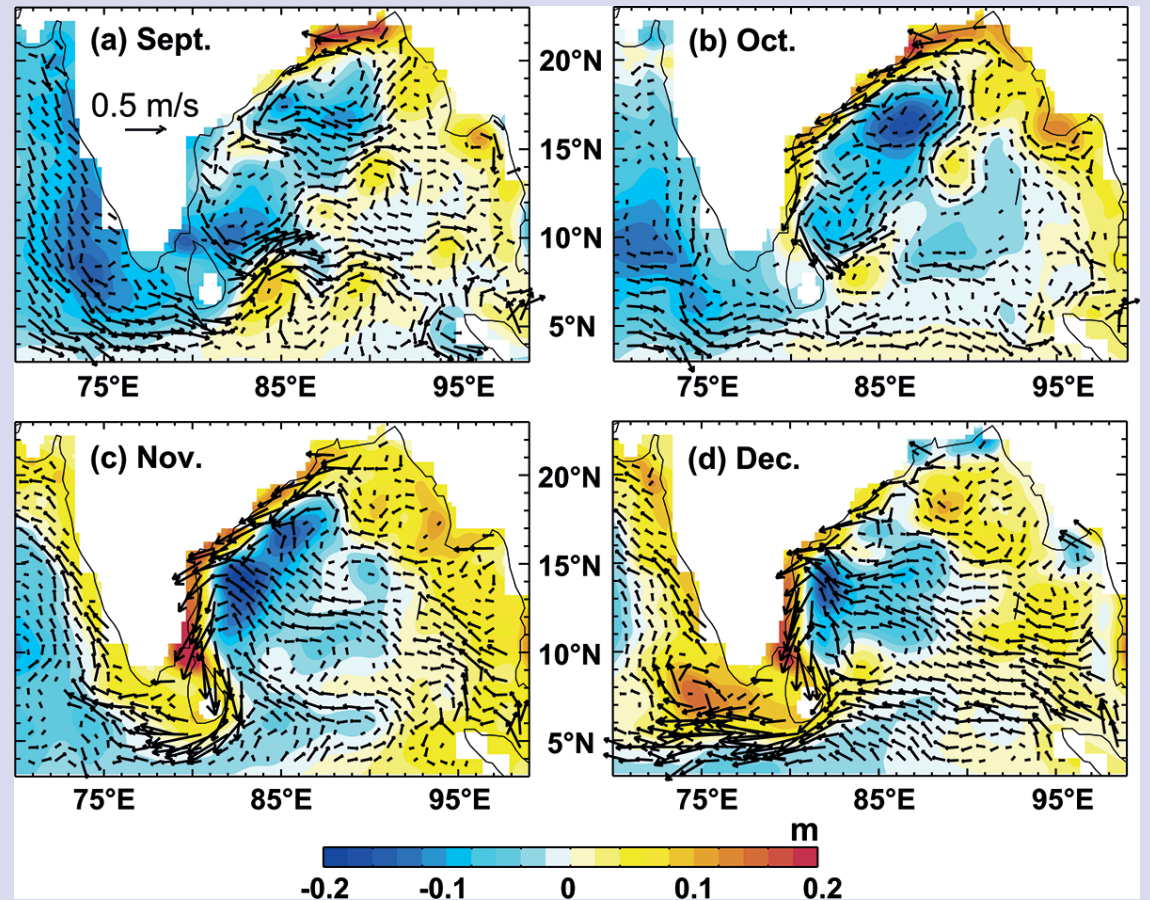

FIG. SB2. Surface currents and absolute dynamic topography from the Geostrophic and Ekman Current Observatory (GEKCO) product (see the online supplement for a description of the datasets used in this paper) in (a) Sep, (b) Oct, (c) Nov, and (d) Dec. 
near Nagapattinam" for a brief description of the fishermen community at one of the stations) were selected all along the coastal region hugged by the East India Coastal Current (EICC) in such a way that there are no rivers, water, or sewage outlets within several kilometers. Every 5 days, except during intense rainfall events, the fishermen collect a water sample in knee-deep to shoulder-deep water in a clean bottle that is thoroughly rinsed with seawater. Those bottles, marked with the date of collection, are routinely collected and brought back to CSIRNIO headquarters in Goa, where the salinity of each sample is then measured using a salinometer.

The salinity signals measured along the coast are typically on the order of several units, and hence much larger than the salinometer accuracy of 0.002 units. While the salinometer-derived salinity measurements are very accurate, the possibility of human errors (e.g., reporting a wrong date on the bottle) or of outliers (e.g., a sample collected during or just after very heavy rainfall) needs to be checked. A simple quality control procedure (described in the supplementary material available at http://dx.doi .org/I0.II75/BAMS-D-12-00243.2) allows rejecting values that are abnormally different from the neighboring measurements. The percentage of discarded values differs for each station but never exceeds $12 \%$.
When this program was initially started, it was not evident that water samples collected at the beach would reflect offshore salinity variations rather than the more local effects of rainfall or groundwater resurgence. We have hence compared the data collected at the beach with an offshore surface salinity dataset collected by CSIR-NIO about $50 \mathrm{~km}$ offshore along a passenger ship track between Chennai, India, and the Andaman Islands (see Fig. 3d for the track, and the supplementary information for a detailed description of all the data sources in this article). The presence of a narrow freshwater tongue hugging the coast of India in the aftermath of the southwest monsoon depicted by Shetye et al. (1996) and Hareesh Kumar et al. (2013) cruise data is confirmed by the November long-term average of the salinity data along the ship track, which displays a 5-unit drop in SSS within $100-150 \mathrm{~km}$ of the coast (Fig. 4a). Neither the state-of-the-art Chatterjee et al. (2012) salinity climatology nor the Antonov et al. (2010) salinity climatology captures the offshore extent and amplitude of the freshening (Fig. 4a). The much wider spatial scale of the coastal freshening seen in these gridded datasets is probably due to the undersampling of surface salinity very close to the coast (see "Salinity observations in the Bay of Bengal") and to the spatial smoothing that is used during the objective

\section{VELIPALAIYAM, A FISHING VILLAGE NEAR NAGAPATTINAM}

The water sample collection site near Nagapattinam is on the beach of a fishing village called Velipalaiyam (Fig. SB3), a couple of kilometers north of Nagapattinam city, in a region that was severely affected by the December 2004 tsunami. This village has about 2,000 inhabitants, most of which belong to the fishing community. The fishermen generally use small, mechanized boats and no big trawlers, which prevent them from going out at sea during the monsoon. None of the boats is equipped with global positioning system receivers, which also prevents the collection of water samples at precise locations from the boats. It is for these reasons that the collection of water samples from the beach itself was favored, because it can be done year-round.

The best fish catches are generally made in May-June and October-
November. There is no cold storage facility in the village, and the fish is generally sold to brokers that transport it to nearby city markets to sell it. The average monthly income in the village is about 160 U.S. dollars, mostly from selling the fish to brokers but also occasionally from construction labor. The village has one government high school, which is attended by most of the children from the village.

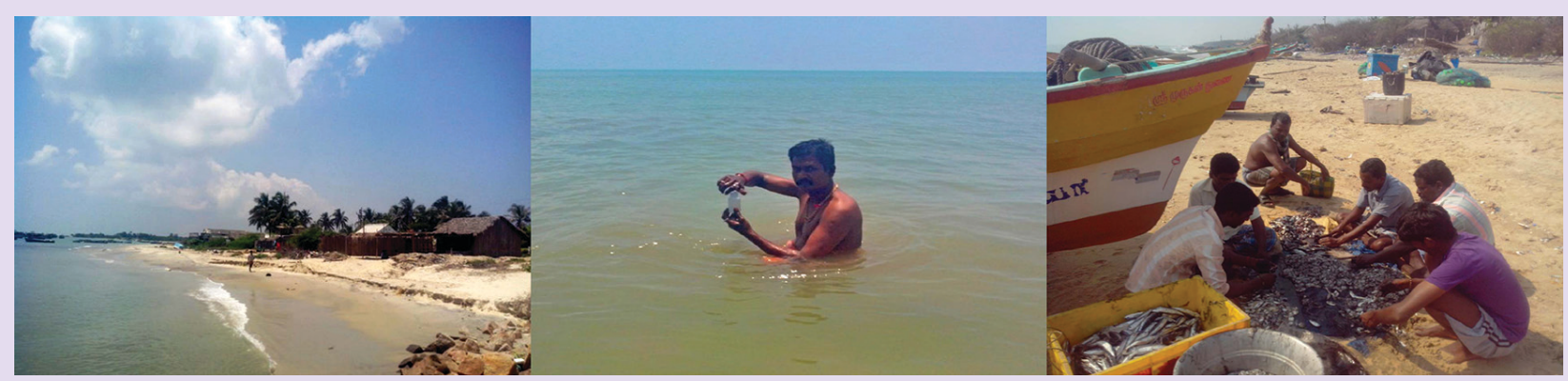

FIG. SB3. (left) Velipalaiyam village, near Nagapattinam, from the shore. (middle) A fisherman collecting seawater. (right) Fishermen sorting the catch before sending it to the local market. 
interpolation to map unevenly distributed salinity observations onto a regular grid [a smoothing with a 444-km horizontal scale is applied in the case of the Chatterjee et al. (2012) and Antonov et al. (2010) climatologies]. While the coastal data are about 2.5 units fresher than the shipborne data within about $25 \mathrm{~km}$ of the coast, its amplitude is consistent with the near-exponential structure of the salinity section close to the coast (see the blue line in Fig. 4a). In addition to the offshore structure, the temporal phasing of the seasonal salinity evolution at the Chennai coastal station agrees well with the climatological seasonal cycle of the shipborne SSS data measured about $25 \mathrm{~km}$ from the coast, with a large salinity drop after the southwest monsoon (Fig. 4b). At this location, the data collected at the beach therefore appear to be representative of offshore salinity, with an intense coastal freshening consistent with the Chennai-Port Blair transect data.

The narrow offshore extent of this river in the sea is consistent with a dominant role of advection by the EICC suggested by Shetye et al. (1996). The EICC starts flowing southward in September (Fig. SB2), as a coastally trapped current (Shankar et al. 1996; McCreary et al. 1996). Around that time, the BoB shows a rather zonally uniform salinity distribution with very fresh (SSS 26) water in the northern BoB and saltier water (SSS $\sim 33$ ) in the central and southern BoB. Figure $5 \mathrm{a}$ shows the salinity distribution in an idealized model starting from this state, and transporting salinity under the effect of a coastally trapped current with the idealized offshore structure of the EICC. The most intense currents at the coast result in a faster advection of the low-salinity water there and create a very narrow fresh strip at the coast that flows southward along the coast and resembles the salinity structure observed in Shetye et al. (1996, Fig. 3d). In the real ocean, oceanic turbulence will, of course, create recirculations and filaments of the coastal freshwater in the offshore saltier water as observed by Hareesh Kumar et al. (2013) in December 1997, and modeled in the eddy-resolving numerical simulations of Benshila et al. (2014; Fig. 5b).

THE RIVER-IN-THE-SEA SEASONAL MARCH. Figure 6 shows the 2005-13 time series of SSS evolution for the eight stations of the coastal surface salinity monitoring network. The stations located in the northern part of the BoB display very large salinity drops (up to 20 units) during and after the summer monsoon. This monsoonal freshening signal generally becomes smaller and occurs later while progressing toward the southern tip of India (a) November SSS climatology off Chennai

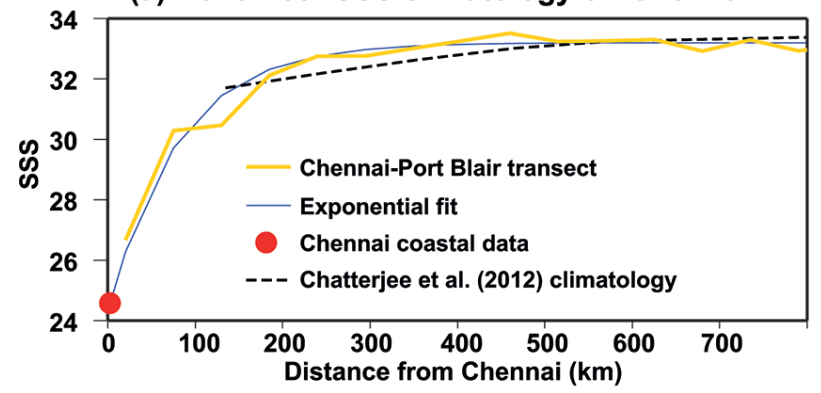

(b) SSS seasonal cycle close to Chennai

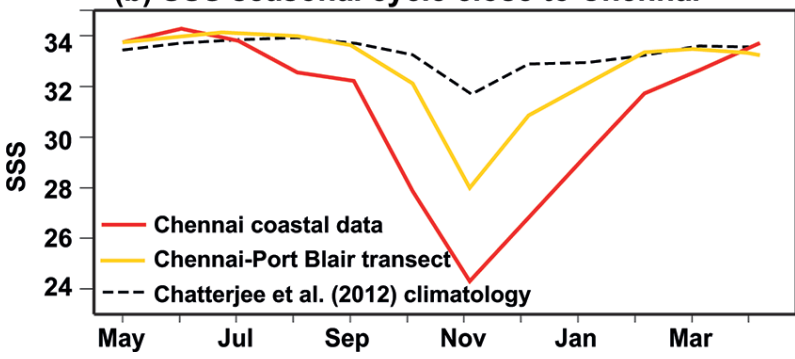

FIG. 4. (a) Nov climatological SSS along the ChennaiPort Blair transect from the coastal station at Chennai (red dot), offshore bottle measurements from the passenger ship (yellow), and the Chatterjee et al. (20I2) climatology (dashed black). Also shown is the exponential fit to the data from the coastal station and Chennai-Port Blair transect (blue). (b) Seasonal evolution of climatological SSS near Chennai from the coastal station (red), the first measurement on the Chennai-Port Blair shipping line (yellow, $25 \mathrm{~km}$ away from the coast), and the Chatterjee et al. (20I2) salinity climatology (first available value about 50 km away from the coast; dashed black). Measurements along the Chennai-Port Blair transect are collected from bucket samples every $50-100 \mathrm{~km}$ by a scientific observer on board a passenger ship that repeatedly plies between the eastern Indian coast line and the Andaman Sea. This dataset spans the Sep 2006-Jan 2013 period with typically a monthly frequency.

(Rameswaram, Tiruchendur), and it is almost nonexistent at Colachel. At most stations along the eastern coast of India, the decrease in salinity occurs rather abruptly, while the return to higher salinity values after the monsoon is generally more gradual.

Figure 7a displays the mean seasonal cycle of SSS at each station. The salinity signal has a very large amplitude all along the eastern coast of India (typically more than 10 units), and it decreases as one travels southward. Figure $7 \mathrm{~b}$ shows the local climatological rainfall at each station. The stations in the northern $\mathrm{BoB}$ experience the largest rainfall during the southwest monsoon (June-September), while the stations in the southern BoB (Chennai and farther south) receive most of the seasonal rains during the northeast monsoon (October and November). 

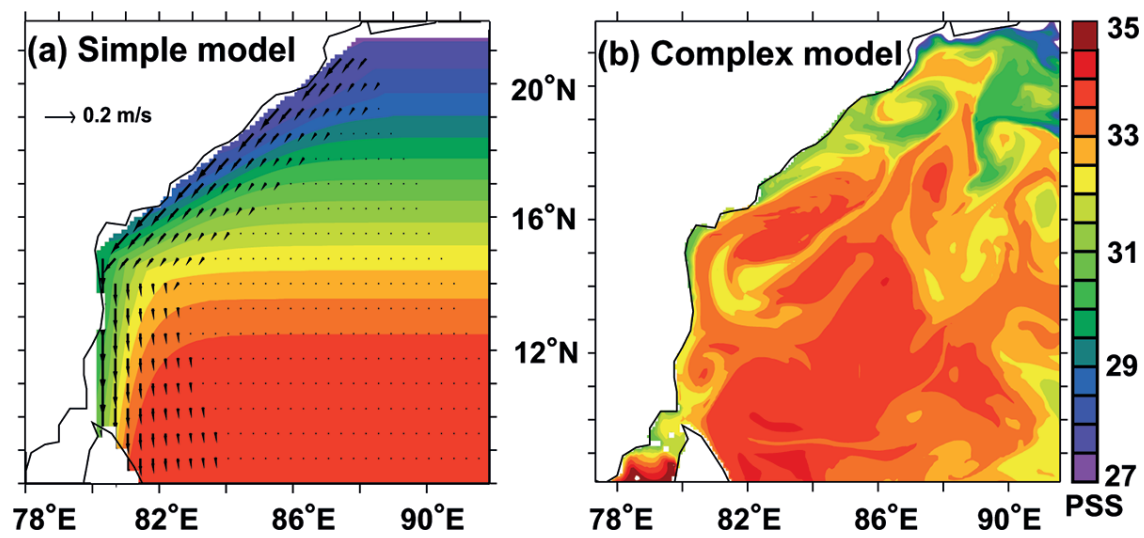

FIG. 5. SSS distribution in Dec in the BoB from (a) an idealized model of salinity transport by the EICC and (b) the $1 / 12^{\circ}$ simulation from Benshila et al. (2014) for 2006. The idealized model is described in "Idealized model of salinity transport by the EICC" of the supplement. It consists of a salt horizontal transport equation, initialized with a zonally uniform salinity that mimics the climatological salinity in the BoB in Sep (i.e., toward the end of the monsoon, before the EICC develops). The salinity of this model evolves under the effect of a specified constant current (displayed by vectors) with an idealized offshore structure that mimics the coastally trapped EICC. The salinity structure in (a) is displayed after 90 days of integration (i.e., toward mid-Dec).
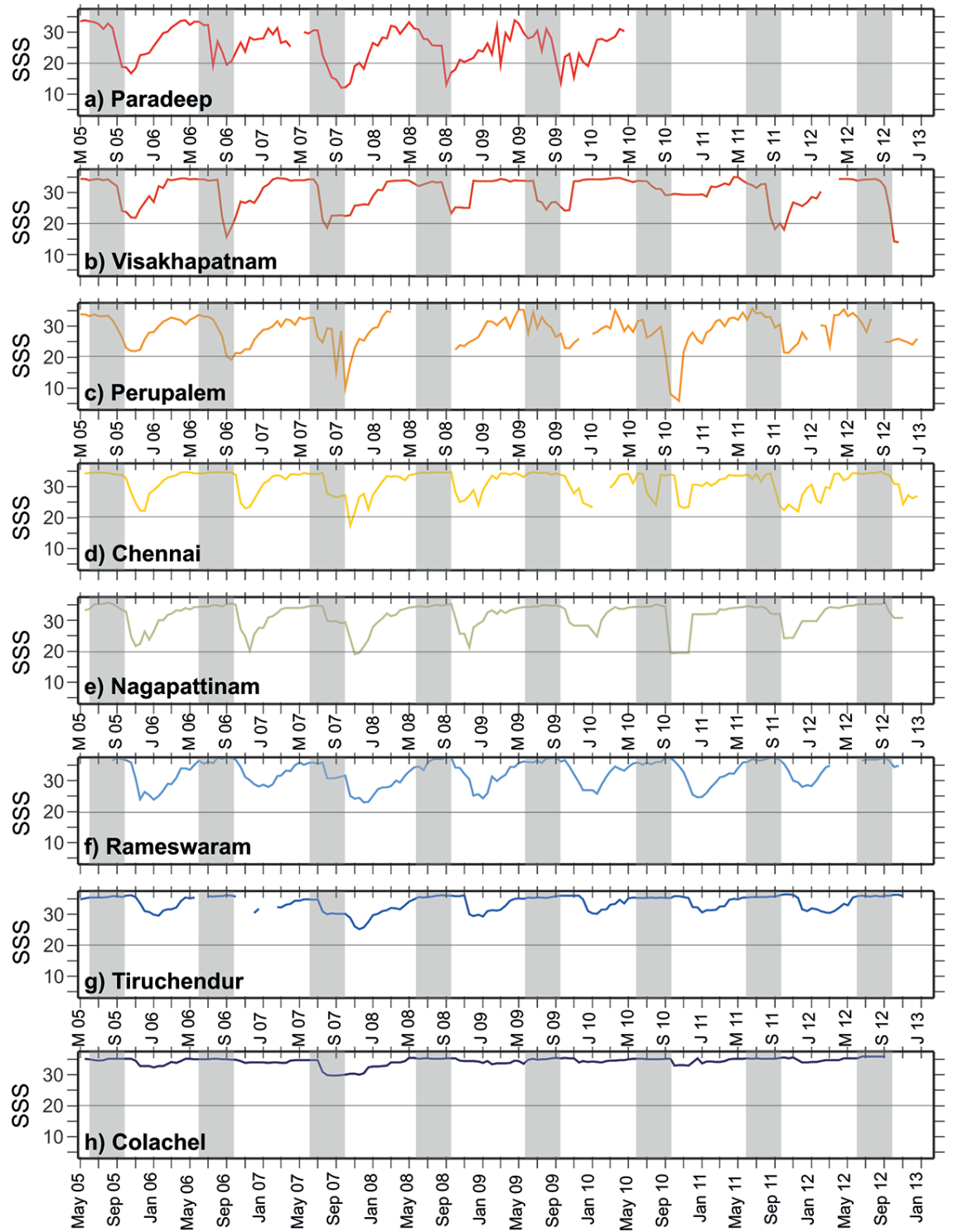

FIG. 6. Bimonthly averaged SSS at the eight coastal stations for the 2005-13 period. The gray shading indicates the summer monsoon period (Jun-Sep).

The massive freshening at the northernmost station (Paradeep) closely follows the seasonal maximum of the Brahmaputra-Ganges discharge (Fig. 7c), indicating the dominant role of river runoff in the northern $\mathrm{BoB}$ in agreement with previous studies (e.g., Han et al. 2001; Rao and Sivakumar 2003; Shetye et al. 1996; Sengupta et al. 2006). The freshening signal occurs progressively later as one travels southward along the coast (the freshening signal reaches Visakhapatnam two weeks later and Tiruchendur 2.5 months later than at Paradeep). Local precipitation does not display such apparent southward propagation. In addition, in Chennai (about $400 \mathrm{~km}$ south of the nearest major river mouth), the salinity decreases abruptly in late September, while local precipitation peaks later, in October-November. Finally, a simple estimation of the effect of local rainfall, assuming a $10-\mathrm{m}$ mixedlayer depth, demonstrates 
that local precipitation can only explain about $10 \%$ of the freshening observed for all coastal stations located south of Paradeep (not shown). These results are clear indications that factors other than local rainfall or runoff from nearby rivers induce this abrupt freshening along the eastern coast, with the apparent southward propagation being consistent with advection by the EICC.

Figure 8 provides a qualitative assessment of the role of advection by the EICC in the southward expansion of the river in the sea, as diagnosed from the coastal stations' network. This figure shows the satellite-derived alongshore surface flow (Sudre et al. 2013) within $75 \mathrm{~km}$ of the coast, along the Indian coast from the mouth of the Ganges to the southern tip of India. The dashed line in this plot indicates the trajectory of a hypothetical drifter traveling at the speed of the EICC flow along the eastern coast and down to the southern tip of India. The onset of the freshening date systematically occurs after the EICC southward reversal and the timing of the freshening observed at the various stations (Visakhapatnam, Perupalem, Chennai, Nagapattinam) roughly matches the timing expected from advection by the EICC. The decrease in the amplitude of the SSS freshening as one progresses south (Fig. 7a) is probably an indication of the mixing with saltier water from below the surface (e.g., Shetye et al. 1996; Benshila et al. 2014) and from offshore (e.g., Hareesh Kumar et al. 2013). The only clear exception to that rule occurs in Perupalem, where a slightly larger freshening signal is observed compared to Visakhapatnam, farther north (Fig. 7a): this may reflect the influence of freshwater discharge from the Godavari, north of Perupalem station.

While the coastal freshening signal is qualitatively consistent with transport by the narrow EICC (in agreement with previous studies, e.g., Han et al. 2001, Jensen 2001, Rao and Sivakumar 2003, and Benshila et al. 2014), the conspicuous increase of coastal salinity after the maximum freshening starts while the EICC is still flowing southward along the eastern coast of India, 2-3 months before it reverses and becomes northward. This new in situ dataset hence suggests that northward advection of Arabian Sea saline water into the BoB by the EICC is not the main process that restores SSS to its premonsoon values, although this process may still contribute to some extend to the steady rise in coastal salinity in January-April at the southernmost stations (e.g., Rameswaram, Tiruchendur). Processes other than alongshore advection, such as shoreward advection of

(a) Climatological SSS evolution at the coastal stations

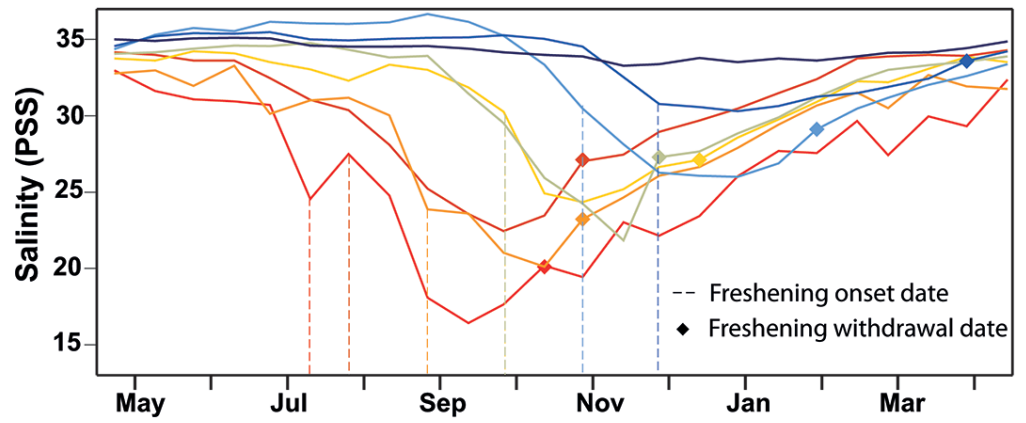

(b) Climatological rainfall evolution at the coastal stations

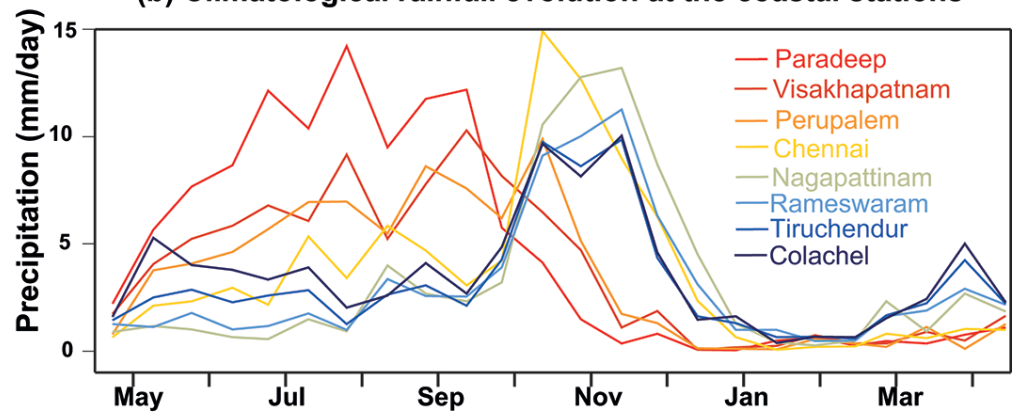

(c) Climatological evolution of major river discharges

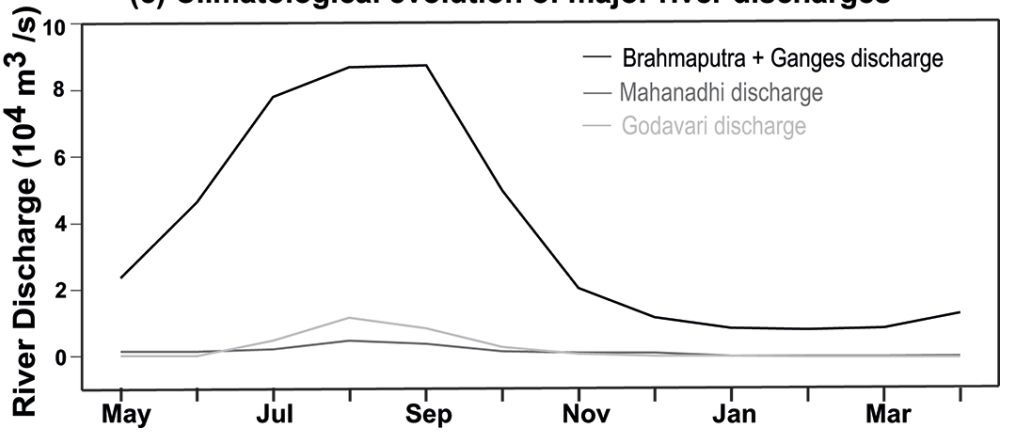

FIG. 7. Seasonal climatology of (a) coastal SSS, (b) local rainfall at each of the eight stations of the coastal SSS measurement network, and (c) discharge of the major rivers along the eastern coast of India. The vertical dashed lines in (a) indicate the dates of the coastal freshening onset (determined as the first date for which salinity is lower than the previous Apr-Jun average minus 3 units), while diamonds indicate the withdrawal dates (determined as the first date when salinity exceeds the lowest salinity plus 3 units). 
saltier waters by eddies or entrainment of subsurface saltier water into the mixed layer, are hence probably responsible for the erosion of the coastal river in the sea.

SUMMARY AND DISCUSSION. Being the only tropical ocean bounded by a continent to the north, the Indian Ocean is home to the most powerful monsoon system in the world. Monsoonal rain and winds induce strong coastal currents and very large river discharges in the northern BoB. To date, the paucity of salinity data has prevented a thorough description of the spreading of this freshwater into the bay. The potential impact of the BoB salinity distribution on

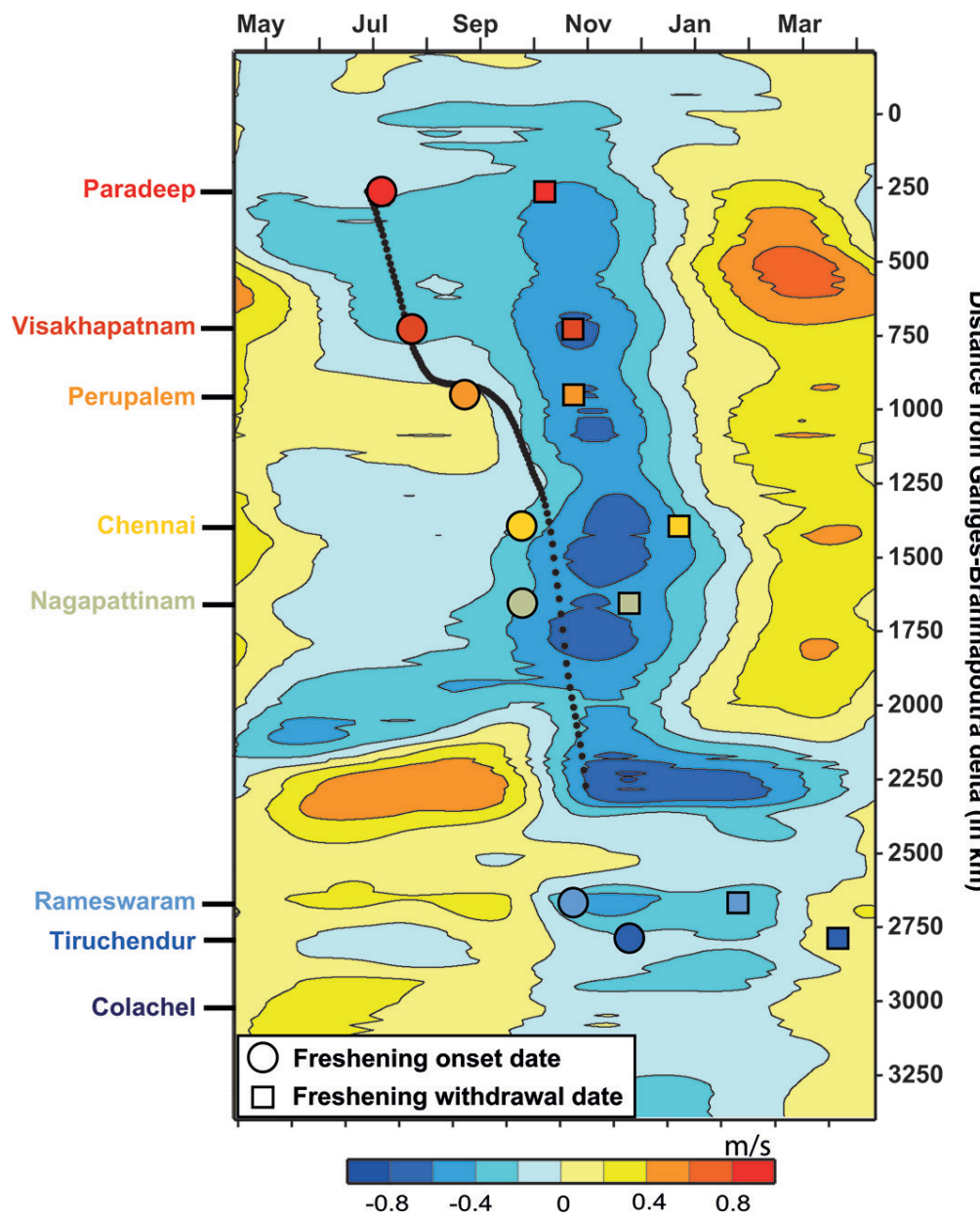

Fig. 8. Alongshore time plot of the seasonal cycle of alongshore currents averaged within $75 \mathrm{~km}$ from the coast. A negative value indicates a southward-flowing current. Names of the coastal SSS measurement network stations are indicated to the left of the $y$ axis, and the distance $(\mathrm{km})$ from the Ganges-Brahmaputra mouth is indicated to the right. The colored dots and squares represent the coastal SSS freshening onset and withdrawal dates, respectively, at each station. The dotted line indicates the trajectory of a virtual surface drifter transported by the alongshore currents and released at Paradeep at the time of the freshening onset. cyclones and regional climate, however, is a strong incentive for a better description of the water cycle in this region. Since May 2005, the CSIR-NIO conducts a program in which fishermen collect seawater samples every 5 days in knee-deep water at eight stations along the Indian coastline. Comparison with open-ocean samples shows that this simple, cost-effective sampling strategy is representative of offshore salinity evolution. This new dataset reveals a salinity drop of more than $10 \mathrm{~g} \mathrm{~kg}^{-1}$ in the northern BoB at the end of the summer monsoon. This freshening signal propagates southward as a narrow ( $100 \mathrm{~km}$ wide) strip along the eastern coast of India, and reaches the southern tip of India after 2.5 months. Satellite-derived alongshorecurrent data show that the southward propagation of the freshwater along the coast is consistent with transport by the EICC, a narrow coastally trapped current that flows southward from October to December. On the other hand, high salinities reappear along the eastern coast of India before the EICC turns northward, suggesting that processes other than alongshore advection are responsible for the ensuing erosion of the coastal freshening.

The occurrence of this river in the sea along the eastern coast of India is probably not a generic feature that can be observed in many locations in the world. Here, it arises from the peculiar geography of the northern Indian Ocean that results in both a massive inflow of freshwater into the semienclosed northern $\mathrm{BoB}$ and in strong coastally trapped currents along the eastern coast of India. In other regions of the world where both the freshwater input from rivers and coastal currents are not as strong and variable as in the $\mathrm{BoB}$, the largescale offshore signal may be smaller and blurred by local signals associated with rainfall or groundwater resurgence.

This study demonstrates the possibility to build a scientifically usable observational network at low cost by relying on local communities from around the Indian Ocean. Our duty as oceanographers is to produce knowledge about the Indian Ocean 
that can be translated into benefits for the society. In return citizens collect the data that help scientists in building that knowledge.

The description of this river in the sea allowed by this innovative program calls for a perpetuation or an expansion of this observing system that may help to monitor salinity variations along the Indian coastline at seasonal and longer time scales. While we have so far focused on salinity measurements, this coastal seawater sampling program could also be used for regular monitoring of other quantities of interest, such as phytoplankton or bacteria. One more potential application of our coastal network concerns the monitoring of seawater composition that could be used to investigate the origins of the freshwater in the river in the sea, since continental water presents a different chemical/isotopic composition than rainwater or open-ocean seawater, for example.

ACKNOWLEDGMENTS. We thank three anonymous reviewers for their comments and suggestions. This work is supported by the Ministry of Earth Sciences through the Indian National Centre for Ocean Information Services (INCOIS). JV, ML, FD, and FP are funded by the Institut de Recherche pour le Développement (IRD). Part of this work was done while ML was a visiting scientist at the National Institute of Oceanography, Goa, India. ML's and JV's research was partly supported by the IFCPAR Proposal 4907. We also thank local fishermen Satyanarayana, Jayabal, Chandu, Shivakumar, Anil, Badal, Pydi Raju, Arun Deol, and Nagaraju for collecting seawater samples systematically at regular intervals. We thank Larsen D'Cruz, Ralph D'Souza, Venugopal Reddy, Nisha Kurian, Joquim Fernandes, Ratna Kumar, and Anuradha, who were involved in transporting and analyzing the samples using Autosal.

\section{REFERENCES}

Antonov, J. I., and Coauthors, 2010: Salinity. Vol. 2, World Ocean Atlas 2009, NOAA Atlas NESDIS 69, 184 pp.

Benshila, R., F. Durand, S. Masson, R. Bourdallé-Badie, C. de Boyer Montégut, F. Papa, and G. Madec, 2014: The upper Bay of Bengal salinity structure in a high-resolution model. Ocean Modell., 74, 36-52, doi:10.1016/j.ocemod.2013.12.001.

Boyer, T. P., and Coauthors, 2009: Introduction. Vol. 1, World Ocean Database 2009, NOAA Atlas NESDIS 66, $217 \mathrm{pp}$.

Chatterjee, A., and Coauthors, 2012: A new atlas of temperature and salinity for the north Indian Ocean. J. Earth Syst. Sci., 121, 559-593, doi:10.1007/s12040 -012-0191-9.
Chelton, D. B., R. A. deSzoeke, M. G. Schlax, K. El Naggar, and N. Siwertz, 1998: Geographical variability of the first baroclinic Rossby radius of deformation. J. Phys. Oceanogr., 28, 433-460, doi:10.1175/15200485(1998)0282.0.CO;2.

Dai, A., and K. E. Trenberth, 2002: Estimates of freshwater discharge from continents: Latitudinal and seasonal variations. J. Hydrometeor., 3, 660-687, doi:10.1175/1525-7541(2002)0032.0.CO;2.

de Boyer Montégut, C., J. Vialard, S. S. C. Shenoi, D. Shankar, F. Durand, C. Ethé, and G. Madec, 2007: Simulated seasonal and interannual variability of the mixed layer heat budget in the northern Indian Ocean. J. Climate, 20, 3249-3268, doi:10.1175 /JCLI4148.1.

Durack, P. J., and S. E. Wijffels, 2010: Fifty-year trends in global ocean salinities and their relationship to broad-scale warming. J. Climate, 23, 4342-4362, doi:10.1175/2010JCLI3377.1.

Durand, F., D. Shankar, F. Birol, and S. S. C. Shenoi, 2009: Spatiotemporal structure of the East India Coastal Current from satellite altimetry. J. Geophys. Res., 114, C02013, doi:10.1029/2008JC004807.

_-, G. Alory, R. Dussin, and N. Reul, 2013: SMOS reveals the signature of Indian Ocean dipole events. Ocean Dyn., 63, 1203-1212, doi:10.1007/s10236 -013-0660-y.

Gadgil, S., P. V. Joseph, and N. V. Joshi, 1984: Oceanatmosphere coupling over monsoon regions. Nature, 312, 141-143, doi:10.1038/312141a0.

Gill, A. E., 1982: Atmosphere-Ocean Dynamics. Academic Press, 662 pp.

Han, W., J. P. McCreary, and K. E. Kohler, 2001: Influence of precipitation minus evaporation and Bay of Bengal rivers on dynamics, thermodynamics, and mixed layer physics in the upper Indian Ocean. J. Geophys. Res., 106, 6895-6916, doi:10.1029/2000JC000403.

Hareesh Kumar, P. V., B. Matthew, M. R. Ramesh Kumar, A. R. Rao, P. S. V. Jagadesh, K. G. Radhakrishnan, and T. N. Shyni, 2013: 'Thermohaline front' off the east coast of India and its generating mechanism. Ocean Dyn., 63, 1175-1180, doi:10.1007/s10236 -013-0652-y.

Jensen, T. G., 2001: Arabian Sea and Bay of Bengal exchange of salt and tracers in an ocean model. Geophys. Res. Lett., 28, 3967-3970, doi:10.1029/2001GL013422.

Kerr, Y. H., and Coauthors, 2010: The SMOS mission: New tool for monitoring key elements of the global water cycle. Proc. IEEE, 98, 666-687, doi:10.1109 /JPROC.2010.2043032.

Levine, D. M., G. S. E. Lagerloef, R. Colomb, S. Yueh, and F. Pellerano, 2007: Aquarius: An instrument to monitor sea surface salinity from space. IEEE Trans. 
Geosci. Remote Sens., 45, 2040-2050, doi:10.1109 /TGRS.2007.898092.

McCreary, J. P., W. Han, D. Shankar, and S. R. Shetye, 1996: Dynamics of the East India Coastal Current: 2. Numerical solutions. J. Geophys. Res., 101, 13993 14 010, doi:10.1029/96JC00560.

McPhaden, M. J., and Coauthors, 2009: RAMA: Research Moored Array for African-AsianAustralian Monsoon Analysis and Prediction. Bull. Amer. Meteor. Soc., 90, 459-480, doi:10.1175 /2008BAMS2608.1.

Millero, R. F., R. Feistel, D. G. Wright, and T. J. McDougall, 2008: The composition of standard seawater and the definition of the reference-composition salinity scale. Deep-Sea Res. I, 55, 50-72, doi:10.1016/j.dsr.2007.10.001.

Neetu, S., M. Lengaigne, E. M. Vincent, J. Vialard, G. Madec, G. Samson, M. R. Ramesh Kumar, and F. Durand, 2012: Influence of upper-ocean stratification on tropical cyclone-induced surface cooling in the Bay of Bengal. J. Geophys. Res., 117, C12020, doi:10.1029/2012JC008433.

Papa, F., S. K. Bala, R. Kumar Pandey, F. Durand, V. V. Gopalakrishna, A. Rahman, and W. B. Rossow, 2012: Ganga-Brahmaputra river discharge from Jason-2 radar altimetry: An update to the long-term satellitederived estimates of continental freshwater forcing flux into the Bay of Bengal. J. Geophys. Res., 117, C11021, doi:10.1029/2012JC008158.

Rao, R. R., and R. Sivakumar, 2003: Seasonal variability of sea surface salinity and salt budget of the mixed layer of the north Indian Ocean. J. Geophys. Res., 108, 3009, doi:10.1029/2001JC000907.

Ratheesh, S., B. Mankad, S. Basu, R. Kumar, and R. Sharma, 2013: Assessment of satellite-derived sea surface salinity in the Indian Ocean. Geosci. Remote Sens. Lett., IEEE, 10, 428-431, doi:10.1109 /LGRS.2012.2207943.

Reul, N., J. Tenerelli, J. Boutin, B. Chapron, F. Paul, E. Brion, F. Gaillard, and O. Archer, 2012: Overview of the first SMOS sea surface salinity products. Part I: Quality assessment for the second half of 2010. IEEE Trans. Geosci. Remote Sens., 50, 1636-1647, doi:10.1109/TGRS.2012.2188408.
Schade, L. R., and K. A. Emanuel, 1999: The ocean's effect on the intensity of tropical cyclones: Results from a simple coupled atmosphere-ocean model. J. Atmos. Sci., 56, 642-651, doi:10.1175/1520-0469 (1999)0562.0.CO;2.

Sengupta, D., G. N. Bharath Raj, and S. S. C. Shenoi, 2006: Surface freshwater from Bay of Bengal runoff and Indonesian Throughflow in the tropical Indian Ocean. Geophys. Res. Lett., 33, L22609, doi:10.1029/2006GL027573.

_- R. G. Bharath, and D. S. Anitha, 2008: Cycloneinduced mixing does not cool SST in the post-monsoon north Bay of Bengal. Atmos. Sci. Lett., 9, 1-6, doi:10.1002/asl.162.

Shankar, D., J. P. McCreary, W. Han, and S. R. Shetye, 1996: Dynamics of the East India Coastal Current 1. Analytic solutions forced by interior Ekman pumping and local alongshore winds. J. Geophys. Res., 101, 13975-13 991, doi:10.1029/96JC00559.

Shenoi, S. S. C., D. Shankar, and S. R. Shetye, 2002: Difference in heat budgets of the near-surface Arabian Sea and Bay of Bengal: Implications for the summer monsoon. J. Geophys. Res., 107, 3052, doi:10.1029/2000JC000679.

Shetye, S. R., A. D. Gouveia, D. Shankar, G. S. Michael, and G. Nampoothiri, 1996: Hydrography and circulation of the western Bay of Bengal during the northeast monsoon. J. Geophys. Res., 101, 14011-14025, doi:10.1029/95JC03307.

Shinoda, T., T. G. Jensen, M. Flatau, S. Chen, W. Han, and C. Wang, 2013: Large-scale oceanic variability associated with the Madden-Julian Oscillation during the CINDY/DYNAMO Field Campaign from Satellite Observations. Remote Sens., 5, 2072-2092, doi:10.3390/rs5052072.

Sudre, J., C. Maes, and V. Garçon, 2013: On the global estimates of geostrophic and Ekman surface currents. Limnol. Oceanogr. Fluids Environ., 3, 1-20, doi:10.1215/21573689-2071927.

Terray, L., L. Corre, S. Cravatte, T. Delcroix, G. Reverdin, and A. Ribes, 2012: Near-surface salinity as nature's rain gauge to detect human influence on the tropical water cycle. J. Climate, 25, 958-977, doi:10.1175 /JCLI-D-10-05025.1. 